University of Nebraska - Lincoln

DigitalCommons@University of Nebraska - Lincoln

Papers in the Earth and Atmospheric Sciences

Earth and Atmospheric Sciences, Department

1991

\title{
Ice-wedge Casts of Wisconsinan Age in Eastern Nebraska
}

William J. Wayne

University of Nebraska-Lincoln, wwayne3@unl.edu

Follow this and additional works at: https://digitalcommons.unl.edu/geosciencefacpub

Part of the Geomorphology Commons, Glaciology Commons, Paleobiology Commons, and the Stratigraphy Commons

Wayne, William J., "Ice-wedge Casts of Wisconsinan Age in Eastern Nebraska" (1991). Papers in the Earth and Atmospheric Sciences. 502.

https://digitalcommons.unl.edu/geosciencefacpub/502

This Article is brought to you for free and open access by the Earth and Atmospheric Sciences, Department of at DigitalCommons@University of Nebraska - Lincoln. It has been accepted for inclusion in Papers in the Earth and Atmospheric Sciences by an authorized administrator of DigitalCommons@University of Nebraska - Lincoln. 
Published in Permafrost and Periglacial Processes, vol 2 (1991), pp 211-223.

doi 10.1002/ppp.3430020305

Copyright (C) 1991 by John Wiley \& Sons, Ltd. Used by permission.

Submitted 10 June 1991; revised 23 July 1991

\title{
Ice-wedge Casts of Wisconsinan Age in Eastern Nebraska
}

\author{
William J. Wayne \\ Department of Geology, University of Nebraska-Lincoln, \\ Lincoln, Nebraska 68588-0340 USA
}

\begin{abstract}
Sand-filled, wedge-shaped structures beneath a thin layer of aeolian sand penetrate a preIllinoian till and gravel in northeastern Nebraska. Interpreted to be relic thermal contraction crack wedges, they provide the first definite evidence in this State of the former presence of permafrost. The wedges are 5- $7 \mathrm{~m}$ apart, 1.8-2.8 $\mathrm{m}$ deep and o.6-0.9 $\mathrm{m}$ across at the top, taper downward to a crack and intersect to form polygons. They are filled with medium sand that contains mostly rounded and frosted grains. Vertical fabric is present in each wedge. Ventifacts lie along the top of the till, which is covered by $0.3-0.4 \mathrm{~m}$ of interlaminated medium and fine sand that grades upward into $1.0 \mathrm{~m}$ of Peoria Loess.

These sand wedges formed in thermal contraction cracks, in dry, windswept areas 25-50 km south of the Late Wisconsinan ice margin, where snow cover was minimal, so that blown sand fell into the open cracks. They probably required mean annual temperatures of $-6^{\circ} \mathrm{C}$ to $-8{ }^{\circ} \mathrm{C}$ or lower, along with strong winds and rapid drops in temperature. Yardang-like topography, beyond the limit of Wisconsinan till across central South Dakota and northeastern Nebraska, is further evidence of exceptionally strong winds parallel to the ice margin during the Late Wisconsinan glacial maximum, between 22 and $18 \mathrm{ka}$.
\end{abstract}

\section{Résumé}

Des structures en forme de coin, remplies de sable pénètrent sous une fine couche de sable éolien dans un dépôt glaciaire et des graviers pré-illinoïens dans Ie NE du Nébraska. Interprétées comme des fentes de gel fossiles formées par contraction thermique, ces structures fournissent la première 
évidence de l'existence ancienne d'un pergélisol dans cet Etat. Les coins sont distants de 5 à $7 \mathrm{~m}$ et s'intersectent pour former des polygones. Ils sont profonds de 1,8 à 2,8 m, larges de o,6 à o,9 m au sommet et s'amincissent en profondeur jusqu'à devenir des fissures. Ils sont remplis de sables de taille moyenne formés principalement de grains arrondis et mats. La disposition verticale des éléments est la même dans chaque coin. Des cailloux éolisés se trouvent près du sommet du dépôt glaciaire qui est couvert par 0,3 à 0,4 $\mathrm{m}$ de sables interstratifiés moyens et fins; au-dessus, ce dépôt passe à 1,0 $\mathrm{m}$ de loess Peoria.

Ces coins à remplissage de sables ont été formés comme des fissures de contraction thermique dans des régions sèches balayées par le vent, à $25 \mathrm{ou}$ $50 \mathrm{~km}$ au S de la dernière limite glaciaire wisconsinienne. La couverture de neige y était minime, de telle sorte que le sable déplacé par le vent tombait dans les fissures ouvertes. Ces formes sont sans doute apparues quand la température moyenne annuelle était de $-6 \mathrm{a}-8^{\circ} \mathrm{C}$ ou plus basse, et pendant une période où existaient des vents puissants et de brusques chutes de température. Une topographie semblable à celle des yardangs, s'étendant au sud du dépôt glaciaire wisconsinien, fournit pour le centre du S Dakota et le NE du Nébraska, une évidence supplémentaire de l'existence de vents exceptionnellement forts, parallèles à la bordure glaciaire, pendant le maximum de la glaciation de la fin du Wisconsin, entre 22 et $18 \mathrm{ka}$.

Keywords: Sand wedges, Wind scour, Yardangs, Nebraska

\section{Introduction}

Prior to about 196o, speculation on whether or not tundra-like conditions, including perennially frozen ground, may have existed along the margin of the Wisconsinan glaciers ranged from no such zone by palynologists (e.g. Potzger, 1951), who found no pollen record of tundra, to a wide and continuous tundra zone across the continent (e.g. Dillon, 1956). Since that time, however, both pollen records and physical evidence demonstrate that such conditions existed but were not as extensive as presented in the more extreme interpretations.

Several kinds of features, both physical and biological, can be used to evaluate the conditions that surrounded the ice margin during glaciations. The most convincing evidence of former permafrost is provided by thermal contraction cracks. Ice wedges form only in permafrost, and generally require mean annual air temperatures of $-6{ }^{\circ} \mathrm{C}$ to $-8{ }^{\circ} \mathrm{C}$ (Pewe, 1966, p. 79) with minimal snow cover. Hamilton et al. (1983) point out, however, that ice wedges can grow where the mean 
annual temperature is apparently - 3.5 oc. Casts form when the permafrost melts, usually the result of climatic warming. In addition, tundra polygons, various kinds of patterned ground, evidence of former solifluction and fossil remnants of taxa that today occupy colder regions than the present have been used as guides to paleoclimatic conditions. Until recently, little evidence had been recorded in the central and northern Great Plains to indicate more severe Pleistocene cold climate conditions except vertebrate and molluscan faunal assemblages. All of the latter had accumulated at considerable distances south of the former ice margins, and indicated climatic conditions ranging from about the same as present to somewhat cooler and moister than present. Mollusca collected from the Peoria Loess in Kansas, for example, show that the area was cooler than now, but little of the faunal material indicates cold conditions (Leonard, 1952). One exception is the sparse pollen record (Baker and Waln, 1985), which indicates the presence of spruce trees in the region during the maximum of the Wisconsinan glaciation.

For many years, wedge-shaped structures ascribed to thermal contraction cracking have been described in the Central Lowlands of the United States (e.g. Frye and Willman, 1958; Wayne, 1963, 1967; Black, 1965; Ruhe, 1969, p. 179; Johnson, 1986, 1990). In the Great Plains, wedge casts have been noted in North Dakota (Clayton, 1980; Clayton and Bailey, 1970; Clayton et al., 1980; Bluemle and Clayton, 1986), Wyoming (Mears, 1981, 1986, 1987), Montana (Colton, 1955), and Alberta (Westgate and Bayrock, 1964; Berg, 1969). Black (1976) and Brown and Pewe (1973) review the distribution of features indicative of former permafrost in North America, and this is also summarized by Washburn (1980, pp. 305-307) and Pewe (1983). Black (1976) pointed out that not all of the reported occurrences of wedge casts were sufficiently well-documented for one to be certain that they all resulted from thermal contraction cracking.

Much of Nebraska lies within the zone suggested by several authors to have experienced 'discontinuous and continuous permafrost' during Wisconsinan time (Pewe, 1983, Figures 9-11). The Late Wisconsinan ice margin reached the northeastern edge of the State (Wayne, 1985, 1988), but no verifiable relic features or landforms indicative of former permafrost conditions have been reported from the State except for one possible 'frost wedge' in Knox County, Nebraska (Flint, 1955, p. 130). In adjacent states, Tipton and Steece (1965, pp. 14-15) described 
sand-filled wedge 'pseudomorphs' in a pre-Wisconsinan till in southeastern South Dakota, and Richard Hammond (personal communication, August 1986) observed sand-filled polygons cutting a light grey till at a construction site at Cherokee, Iowa (Figure 1).

A veneer of loess completely obscures the surface on which thermal contraction cracking would have occurred in that part of Nebraska most likely to have been affected by periglacial conditions. Exposures that cut through the loess into underlying materials are uncommon. Nevertheless, a spectacular and well-studied site is a former gravel pit near Hartington, Nebraska. A second is northeast of o 'Neill, and a third site of possible ice-wedge casts or sand-wedge relics, now destroyed, was observed near Osmond (Figure 1). Other sites farther south, in east-central Nebraska, display features indicative of solifluction (Figure 1), although permafrost would not have been needed to form them.

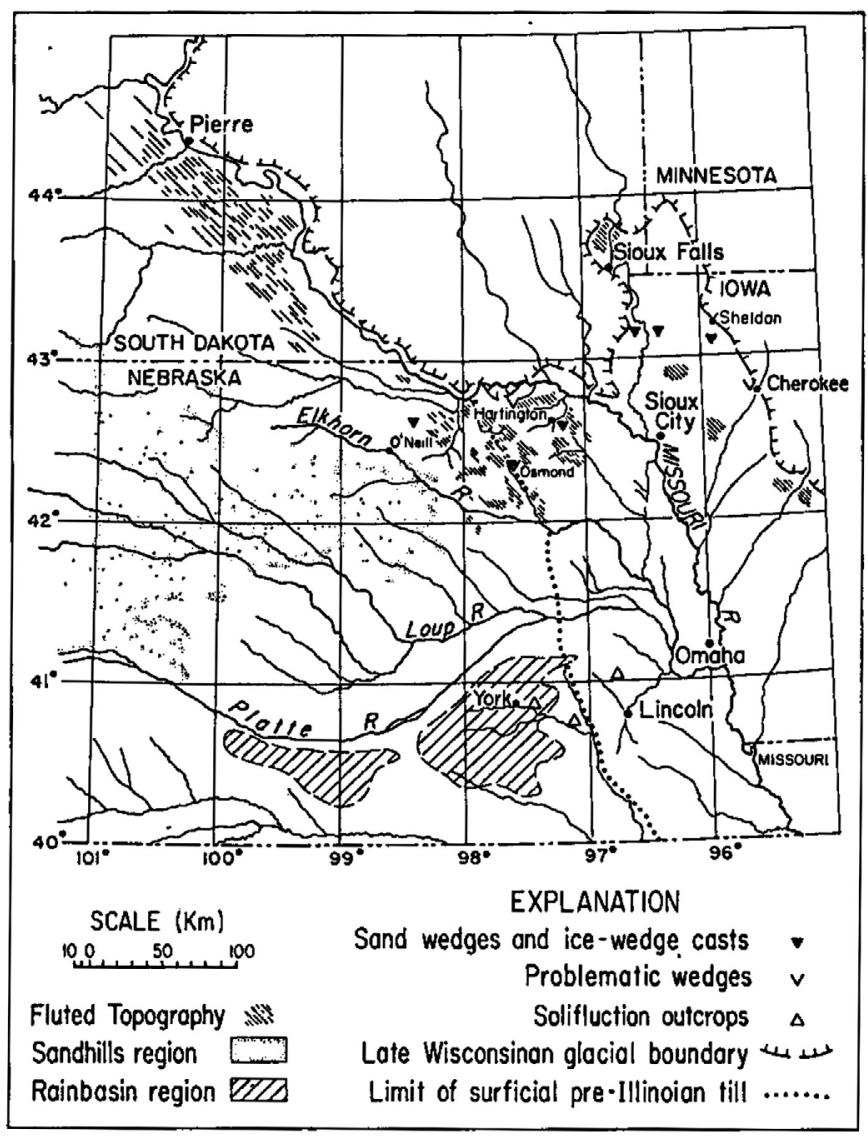

Figure 1. Map of eastern Nebraska and adjacent parts of Iowa and South Dakota showing glacial boundaries, wedge sites, areas of fluted topography, the 'Rainbasin' area and the Sandhill Region. 


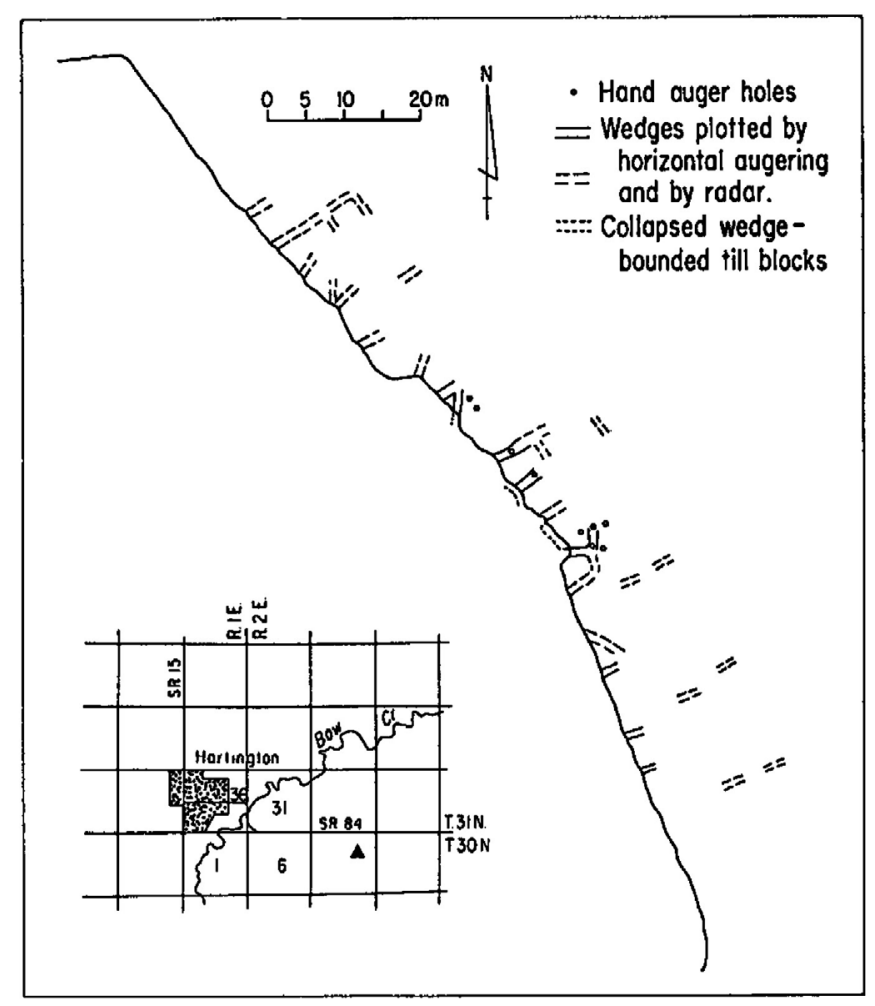

Figure 2. Map of edge of pit face at Hartington landfill, showing distribution and orientation of sand-filled wedges.

\section{Hartington and O’Neill Exposures}

In 1983, 17 sand-filled, wedge-shaped structures that penetrate till were examined and mapped along the vertical face (Figure 2) of a former gravel pit $3.2 \mathrm{~km}$ southeast of Hartington, northeastern Nebraska (Figure 1). The till overlies cross-bedded gravelly sand and ranges in thickness from nearly $4.0 \mathrm{~m}$, in the middle to a pinch out at all edges. Most of the wedges are about $1.8 \mathrm{~m}$ in depth, but they range from 0.6 $\mathrm{m}$ to $2.1 \mathrm{~m}$, and most of them are between $0.6 \mathrm{~m}$ and $0.9 \mathrm{~m}$ across at the top. The wedge tops are even with the top of the till. A discontinuous layer of pebbles and cobbles, most showing wind abrasion on the northwest edges, lies till and wedges are covered by $30-40 \mathrm{~cm}$ of horizontally interlaminated fine and medium sand (Figure 3) that grades upward into $0.8-1.0 \mathrm{~m}$ of loess. The lower $60 \mathrm{~cm}$ of the loess is calcareous and contains small concretions of calcium carbonate (Table 1), typical of the Peoria Loess in northeastern Nebraska. 
Table 1. Section measured in highwall of abandoned gravel pit, now Hartington municipal landfill site, IN SW1/4 NE1/4 SEC.5, T30N, R2E; altitude at surface 439 m (Coleridge Quadrangle). Numbered units correspond to numbers on edge of Figure 3.

9. Loam, dark brown (10YR4/3), platy, friable, calcareous

$0.20 \mathrm{~m}$

8. Loam, sl clayey, yellowish brown (10YR5/4), granular structure, calcaeous with moderately abundant $\mathrm{CaCO}_{3}$ nodules

$0.25 \mathrm{~m}$

7. Loam, yellowish brown (10YR5/4), calcareous with scattered popcorn-like CaCo3 concretions

$0.30 \mathrm{~m}$

6. Silt and sand, yellowish brown (10YR5/4 to 6/4), medium- to fine-grained, horizontally bedded with thin lenses of coarse sand; scattered pebbles and cobbles along base, calcareous

$0.50 m$

5. Till, pale yellowish grey (2.5Y7/1 to 7/4, mottled), pebbly, clayey, very compact; yellowish- brown (10YR 5/S) zones 1 to $4 \mathrm{~cm}$ wide along fractures, secondary $\mathrm{CaCO}_{3}$ nodules present in some fractures; calcareous; upper part contains sand-filled wedge-shaped pendants, some as large as $90 \mathrm{~cm}$ across at top and $2.0 \mathrm{~m}$ deep

4. Till, pale yellow (5Y7/3), mottled, calcareous, pebbly, laminated, very compact

3. Till, white (2.5YS/2), strongly calcareous, cemented

2. Gravelly sand, mostly pebble-sized clasts but contains some cobbles and boulders; large cross-beds dip $25^{\circ}$ towards $\mathrm{N} 80^{\circ} \mathrm{E}$; some larger clasts are armored mud balls that consist of till

The wedges are more or less uniformly spaced from $5 \mathrm{~m}$ to $7 \mathrm{~m}$ apart. Hand augering and traverses with ground-penetrating radar demonstrated that the wedges form a three-dimensional polygonal network (Figure 2). Each wedge is filled with moderately well-sorted medium sand. The sand appears massive, but when dry and windetched, or brushed gently, vertical fracture traces can be observed (Figure 4). The till host material is fine-grained (40\% smaller than 4 $\mu \mathrm{m})$ and contains few pebbles and cobbles. Clay minerals' are smectite, illite and hydromicas. Although pebbles are infrequent, a fabric study shows a strong $\mathrm{S} 75^{\circ} \mathrm{W}$ orientation. No deformation was observed in the massive till adjacent to the wedges and insufficient pebbles were found in that zone to make fabric studies possible. Limonite-stained fractures 5-10 cm apart in the till adjacent to the wedges, however, may be compression-release structures.

The sand that fills wedge-shaped structures that form a polygon pattern northeast of O'Neill (Figure 1) contrasts strongly with the poorly sorted gravel host material in texture, color and weathering profile. One sand-filled wedge visible in a roadside ditch is 1.3 $\mathrm{m}$ across at the top and narrows to $0.4 \mathrm{~m}$ where it crosses the ditch 


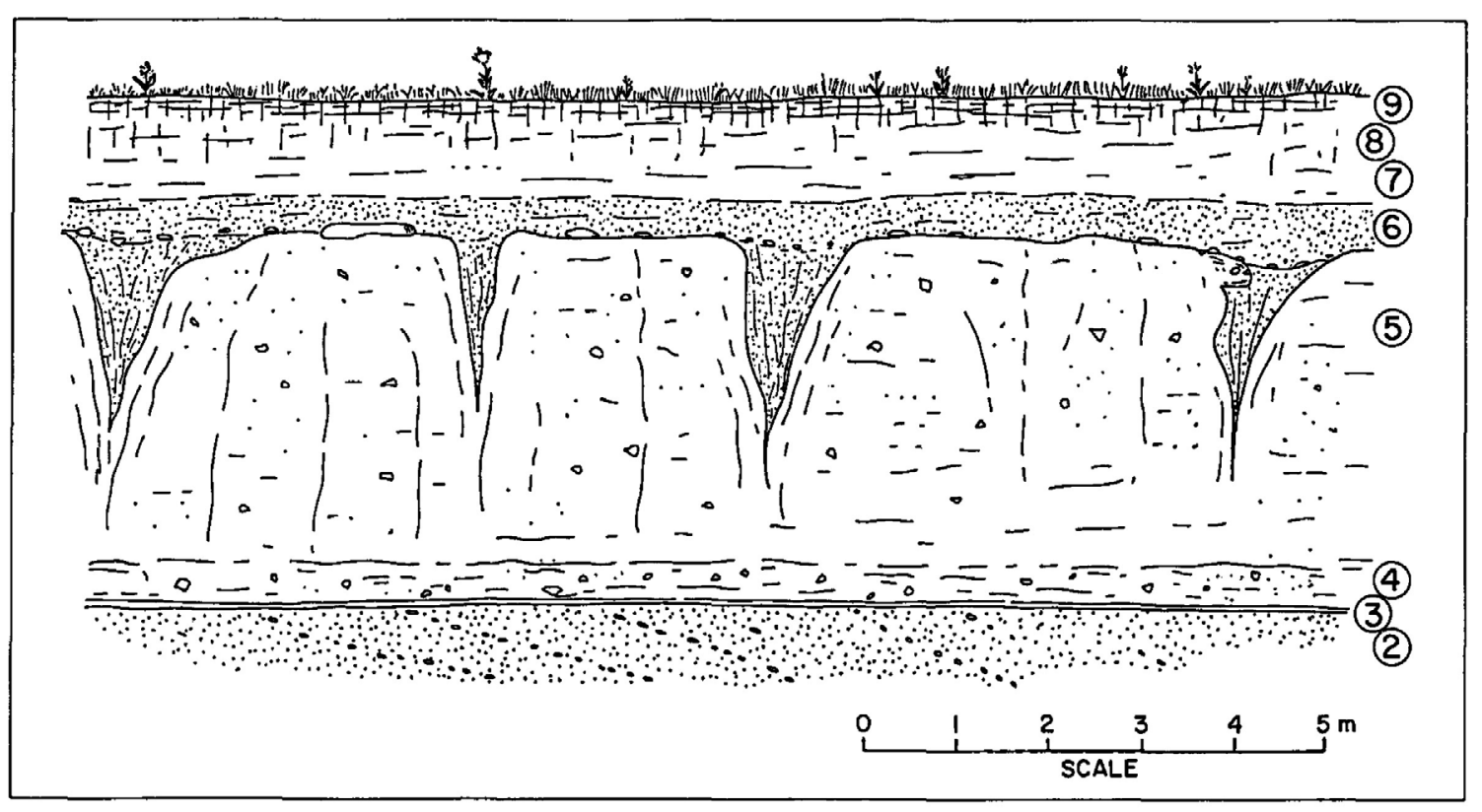

Figure 3. Sketch of part of pit face at Hartington landfill. Numbers refer to the units described in Table 1.

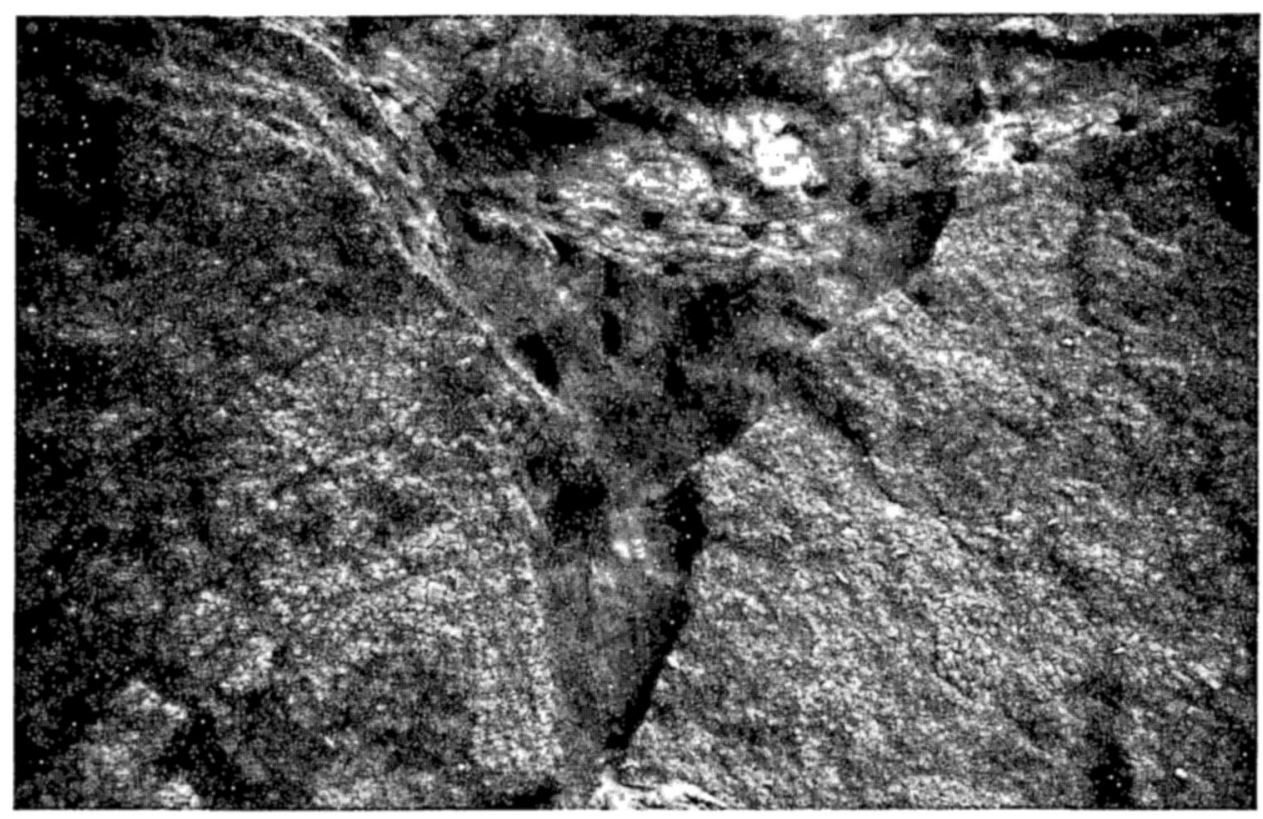

Figure 4. 2.0 $\mathrm{m}$ deep wedge in central part of exposure at the Hartington site. Vertical traces are present in the sand that fills it. Note also the unweathered surface of the till, and the horizontally laminated sand that overlies the wedges at this location 
floor $1.0 \mathrm{~m}$ below the top and intersects with other wedges. Auger borings showed the bottom of the wedges to be about $2.0 \mathrm{~m}$ below the present land surface. The yellowish-brown (10YR4/4) sand that fills the wedges is loose and consists almost wholly of spheroidal, rounded, frosted grains. It looks massive, but a few granules mark vertical traces. The host material is compact, light-yellowish-brown (2.5 $\mathrm{Y} 6 / 4)$, clayey gravelly sand. The top $20-30 \mathrm{~cm}$ displays a clayey, brown $(7.5 \mathrm{YR} 4 / 4) \mathrm{B}$ horizon. Both the wedge and gravel are covered by $30-40 \mathrm{~cm}$ of brown $(1 \mathrm{OYR} 3 / 4)$ sandy loam.

In addition to the Hartington and O'Neill exposures, recent (1989) grading has exposed sand-filled wedges in till along some of the roads near Hartington (Guthrie, 1990). Three wedge-shaped structures that contain sand and penetrate till beneath thin loess were observed in cross-section in a sand pit at Osmond (Figure 1). This exposure was destroyed by earthmoving equipment before the features could be examined carefully, so their origin is questionable. Earlier, however, Todd (1899, p.77) reported large, sand-filled, wedgeshaped cracks in till overlain by a thin sheet of stratified sand in exposures east of Osmond.

Similar wedge-shaped structures filled with frosted, sub-spherical grains of medium sand that form polygons in till 4 to $5 \mathrm{~m}$ in diameter (Figure 5) and as much as $2 \mathrm{~m}$ deep have been exposed on the base of a landfill near Sheldon, Iowa.

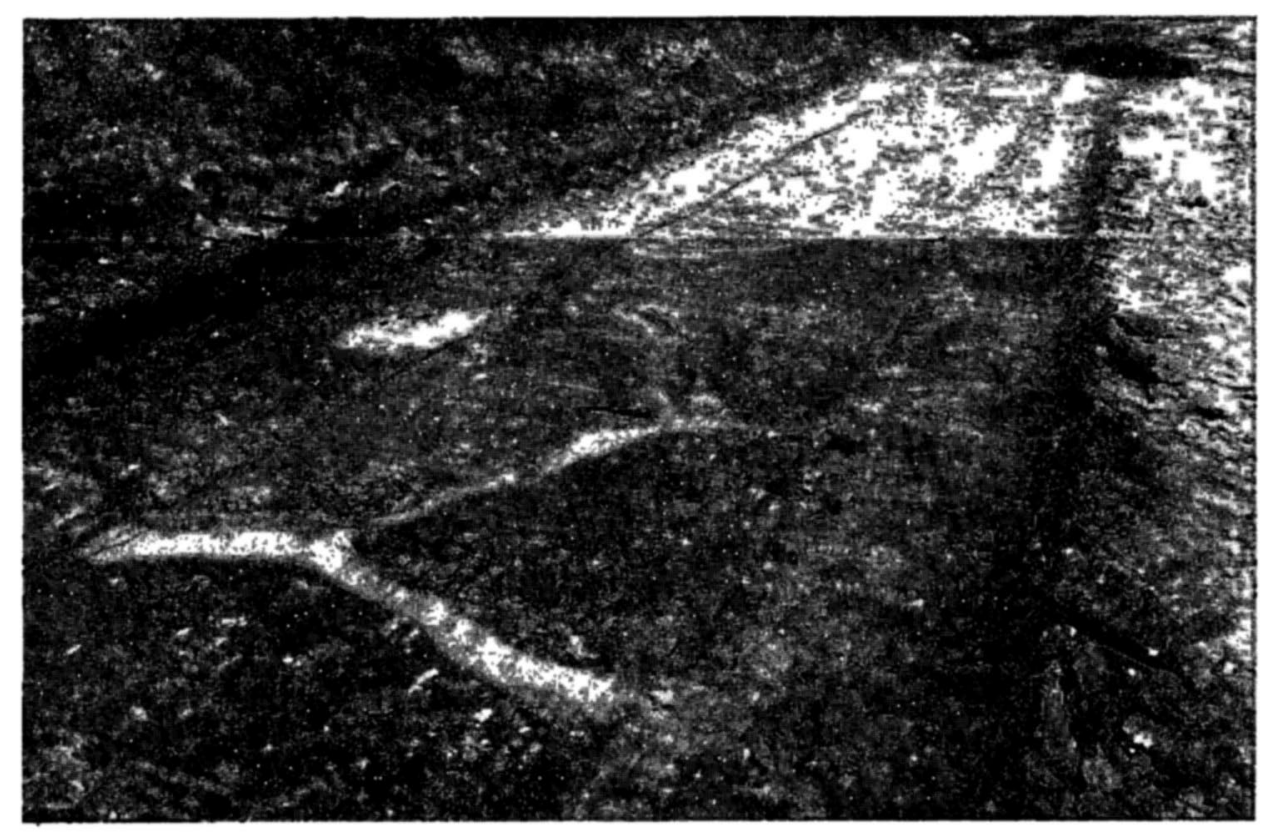

Figure 5. Polygonal pattern of sand wedges exposed in base of landfill near Sheldon, Iowa. 


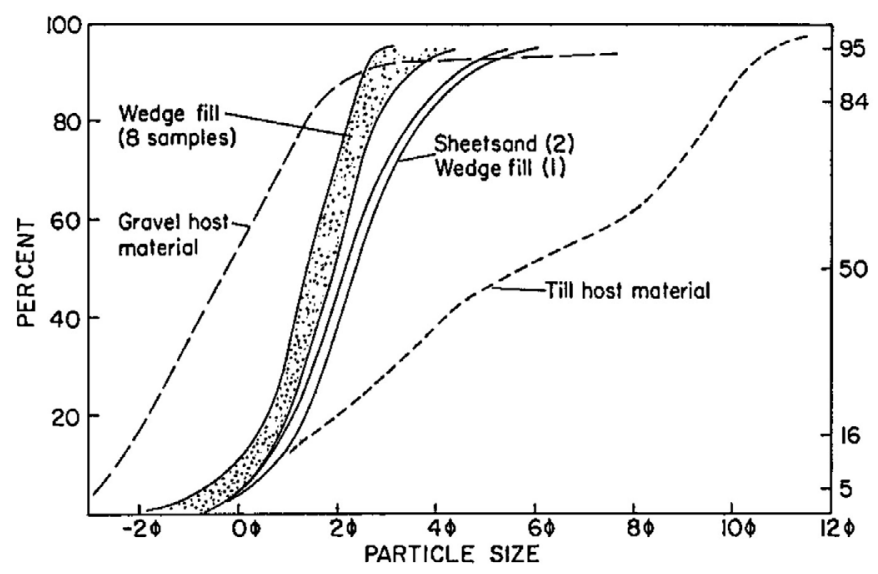

Figure 6. Grain-size distribution curves of sand within and directly above wedges and of the host materials, Hartington and O'Neill wedge sites.

Nearly all samples collected from the sediments that fill the wedges at Hartington and O'Neill are similar with respect to median and mean grain size, degree of sorting and symmetry of distribution (Figure 6). Samples from the basal $10 \mathrm{~cm}$ of the horizontally laminated sand sheet lying directly above the wedges and host till are finer-grained and less well-sorted, and the grain size distribution is strongly fine-skewed.

Sphericity of the grains that fill the wedges is high; most are nearly equidimensional, rounded and highly to moderately frosted. Clear quartz grains dominate all size grades (70-90 \%). Among the larger sizes, $\sim 0.35 \mathrm{~mm}$, about one-quarter of the grains are chert, feldspars and rock fragments. Among the smaller sizes, S $0.25 \mathrm{~mm}$, rock fragments diminish in frequency but hornblende is present.

The sand that fills the wedges has been wind transported. It is finergrained than the sand in the wedge infillings near Edmonton (Berg, 1969), but is coarser than that found in wedge infillings on the Arctic Coastal Plain (Carter, 1983). The sand is coarser and less well-sorted than that of dunes in the Nebraska Sandhill Region (Ahlbrandt and Fryberger, 1980), but compares well in both texture and sorting with the 'Younger Cover Sand' of Denmark (Kolstrup, 1983) and 'Aeolian Subfacies A' in the Netherlands (Ruegg, 1983). The thickness (30-40 $\mathrm{cm}$ ) of the overlying thin sand sheet, its alternation of medium and fine sand laminae, and the sorting and skewness of grain size are similar to the 'Older Cover Sands' of Denmark (Kolstrup and Jorgensen, 1982; Kolstrup, 1983) and' Aeolian Subfacies B' of the Netherlands (Ruegg, 1983). 
No soil profile had developed above the till, but through the till, and some of the joints have nodules of chalky secondary carbonate along them; both features are characteristic of the $\mathrm{C}$ horizons developed in pre-Illinoian surface tills in eastern Nebraska (Wayne, 1985). A lag of pebbles and cobbles lies along the contact of the till and the overlying laminated sand cover. Quartzite clasts that protrude more than $2 \mathrm{~cm}$ above the contact have been beveled and polished along their northwest edges. Only sandblasting from strong, unidirectional winds would produce such features. Similar ventifacts were observed elsewhere in nearby road cuts. The wedges occur on broad, gently sloping hilltops. In the center of the Hartington site, where the till surface is virtually horizontal, a few pebbles and cobbles mark the contact between the top of the wedges and the overlying sand. To the north and south, however, where the buried till surface slopes from $1^{\circ}$ to $7^{\circ}$, small tongues of diamicton extend downslope above some of the wedges, partly covering the sand that fills them (Figure 3).

The wedges are overlain by a thin cover of laminated sand and by loess which postdates the wedges and cover sand. On the west end of the hill, a west trending ravine eroded in the underlying gravel has been partly filled with loess that thickens from $1 \mathrm{~m}$ at the top of the exposure to $4 \mathrm{~m}$ downslope to the south. The loess evidently drifted, like snow behind an obstacle, onto the lee side of the ridge. This loess bank contains a sparse mollusca fauna (Table 2) in two layers of granules and pebbles that indicate sheet wash. The most distinctive is Oreohelix strigosa berryi, an alpine species reported from localities in $\mathrm{Ne}-$ braska, Iowa and Illinois (Simpson, 196o, pp. 82-3; Frest and Rhodes, 1981). Other species indicative of cool to cold climate are Vertigo modesta, Columella alticola, and Discus shimeki.

Table 2. Land mollusks collected from the Peoria Loess at the Hartington landfill site

\begin{tabular}{lrll} 
Species & Number & Region & Climate \\
\hline Oreohelix strigosa berryi & 6 & Alpine; MT, WY & Cool to cold \\
Discus shimeki & 23 & Alpine-subarctic; N. Ont and BC to Colorado & Cool to cold \\
(Snail eggs, probably Discus) & 19 & & Cool to cold? \\
Succinea gelida & 44 & Form species & Cool? \\
Succinea grosvenori & 21 & Form species & Cool to cold \\
Pupilla muscorum & 4 & Holarctic, alpine & Cool to cold \\
Vertigo sp. & 1 & & Cool \\
Columella alticola & 20 & Holarctic, alpine; Canada, Colorado &
\end{tabular}




\section{Origin and Significance}

The wedge-shaped structures in Nebraska could have formed in a number of ways; the principal ones are desiccation and thermal contraction, although tensional fractures of various origins can, if filled with sediment, be preserved. Desiccation cracks are most common in materials high in smectitic clays, may extend downward as much as 2-3 $\mathrm{m}$ and may contain sand. Normally, however, they are slender, and polygons formed by their intersection are small, commonly less than $1 \mathrm{~m}$ across. Desiccation during hot, dry summer months, along with the water demands of deep-rooted grasses, causes narrow cracks to form at the surface in the clayey tills of eastern Nebraska today. These fractures, however, which typically are 1-2 cm wide and probably 1-2 $\mathrm{m}$ deep, close upon wetting and re-expansion of the mixed-layer and expanding lattice clays in the till. Giant desiccation cracks are known in some areas in South Dakota, where Pierre Shale, a rock unit high in expanding lattice clays, outcrops (White, 1970), but their tops are bridged by $40-60 \mathrm{~cm}$ of soil and the cracks are not open to the surface. Large desiccation cracks and polygons have formed on some of the playas of Nevada and southern California (Neal and Motts, 1967) as a result of water table lowering during droughts. However, the climate of northeastern Nebraska differs greatly from that of Nevada, and the southwestern US features are in playas, not on hilltops. The presence of moisture-loving cold-climate mollusca in nearby sediments also indicates that hot dry climatic conditions were unlikely.

Thermal contraction cracks form wherever an insulative snow cover is thin or absent, and ground temperatures in frozen earth drop sufficiently such that the tensile strength of the frozen material is exceeded by the stresses from thermal shrinking. Seasonally frozen ground may also develop thermal contraction cracks that have a polygonal pattern. They form when the surface is saturated, frozen and virtually free of snow, and when air temperature drops rapidly, from about $\mathrm{o}{ }^{\circ} \mathrm{C}$ to $-10^{\circ} \mathrm{C}$ in a few hours (Washburn et al., 1963; Svensson, 1988). The dimensions of such cracks and related polygons, however, are significantly smaller than the ones described here, and preservation would be unlikely. In regions of permafrost, snow melt from the surface infiltrates the crack and freezes. The ice vein then becomes a zone of weakness that reopens during thermal contraction of the materials (Lachenbruch, 1962). When ice in the wedge melts, materials from the active layer and the walls of 
the ice wedge slump into the void, sometimes forming a chaotic accumulation (Black, 1965; Pewe, 1966). Sand wedges result where thermal contraction cracks form in areas of strong winds that keep the surface blown free of snow and sweep a thin sheet of sand across the bare surface (Pewe, 1959; Romanovskij, 1973). Loose sand drops into the open fractures, preventing the host material from closing completely when temperatures rise. Repeated thermal contraction cracking creates a series of vertical fracture traces in sand wedges. Berg (1969) pointed out features that indicate a permafrost origin for the sand wedges near Edmonton; most of these characteristics are present in the Hartington, O'Neill and Sheldon wedges.

The size of the wedges at Hartington, O'Neill and Sheldon is typical of a frost origin. Moreover, the width-to-depth ratio of the sand wedges is about 1: 2; most desiccation cracks are much narrower. Soil auger probing, both horizontally into wedges and vertically through the cover sand and loess, shows that the Hartington wedges extend $2 \mathrm{~m}$ or farther into the bank and join others to form a polygonal pattern. Ground-penetrating radar indicated a few wedge-shaped openings in the till surface beneath loess and sand (Figure 2). Joint blocks that fall from the pit face break free along wedges that are roughly parallel with the face of the exposure. Typically, in bedded host materials, the sediment surrounding the sand wedges is upturned; because the Nebraska wedges are in till and gravel, both of which are massive, no deformations can be seen.

The wedges examined terminate downward in a single sand-filled crack rather than the multiple veins described by Berg (1969) and by Carter (1983). All the Hartington, O'Neill and Sheldon wedges are filled with aeolian sand, and all display vertical lineations. Although a slumped mass of till was observed near the top of one wedge, no other slumped materials or structures were noted within any of the wedge fillings. Because ice-wedge casts are characteristically infilled with material slumped from the adjacent walls, their absence, and the presence of vertical fracture traces instead, suggest that the original wedges were sand-infilled rather than ice-infilled (Black, 1965). The most reasonable interpretation is that they formed when continuous permafrost was present, as is the case in areas where sand wedges are forming today.

Actively growing sand wedges have been observed in Antarctica (Pewe, 1959; Berg and Black, 1966) but evidently have not been reported from other regions (Washburn, 1980, pp. 110-111). The mean 
annual temperature at McMurdo, Ross Island, near regions of active sand wedges, is $-17{ }^{\circ} \mathrm{C}$; precipitation is $160-200 \mathrm{~mm} / \mathrm{yr}$, mostly as snow; and mean annual wind velocity is $22.5 \mathrm{~km} / \mathrm{h}$ (Berg and Black, 1966). Thus, it seems that sand wedges form only under cold arid conditions, in regions of continuous permafrost, where a winter snow cover is thin to absent, a supply of sand is available and strong winds exist. Although Karte and Liedke (1981) and Karte (1983) suggested that sand wedges probably require mean annual air temperatures of from $-12{ }^{\circ} \mathrm{C}$ to $-20{ }^{\circ} \mathrm{C}$ or lower, with rapid temperature drops and very low precipitation, it seems likely that strong winds, a sand source and a snow-free surface would be the more critical factors than temperatures significantly lower than the $-6{ }^{\circ} \mathrm{C}$ to $-8{ }^{\circ} \mathrm{C}$ thought necessary to initiate thermal contraction cracking.

It is unlikely that temperature and precipitation values in northeastern Nebraska, when the sand wedges near Hartington and o 'Neill formed, were as low as those of the Antarctic today. However, they must have been low enough for permafrost to exist and dry enough to preclude the formation of ice in the thermal contraction cracks before they could be filled with sand. An alternative interpretation is to regard the wedges as sand-filled ice-wedge casts. In either case, the supposition that strong winds were common near the ice margin in Nebraska is supported by additional evidence. This includes aligned linear ridges and troughs and the absence of pre-Wisconsinan soil profiles on the surface of the sub-loess till except in highly protected sites. This evidence is now discussed briefly.

\section{Pleistocene Wind Action}

Much of the region beyond the Late Wisconsinan glacial limit in central South Dakota and northeast Nebraska has a distinctive fluted topography oriented $N 45 D W$. These features are evident on airphotos and topographic maps (Figure 7). Similar linear patterns are associated with oriented drainage in central and southeastern South Dakota (Crandall, 1958, pp. 45-49; White, 1961; Tipton and Steece, 1965) and in western Iowa (Hallberg, 1979). Although some troughs between aligned ridges are followed by streams, most are not; rather, swarms of low ridges and troughs that average about $375 \mathrm{~m}$ apart and 1300$1400 \mathrm{~m}$ long, with relief that varies from 2 or $3 \mathrm{~m}$ to more than $15 \mathrm{~m}$, 


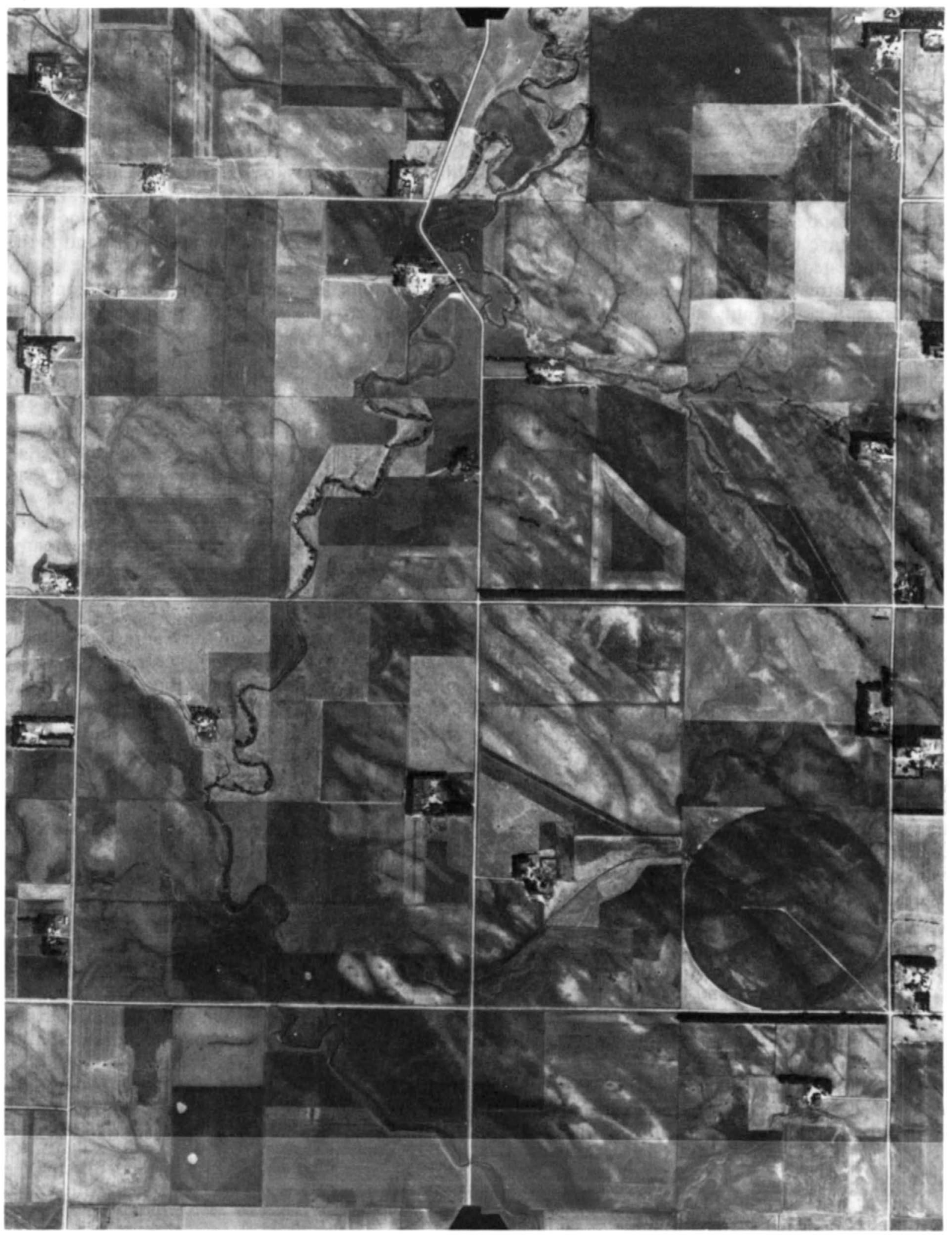

Figure 7. Aerial photo of a part of northeastern Nebraska about $20 \mathrm{~km}$ WSW of Hartington and $3 \mathrm{~km} \mathrm{~N}$ of Osmond, showing linear ridge and trough pattern of the topography. The stream that cuts through fluted terrain is the North Fork of the Elkhorn River. 
disappear into terrain that shows few or no aligned features. The underlying material is till, a till cap over gravelly sand or loess in northeastern Nebraska, although in a few places it is Pierre Shale and Niobrara Chalk. It is Pierre Shale or till in South Dakota. A loess cap is very thin to absent where the oriented topography is well developed in the northeastern edge of Nebraska, but areas of thick loess-5 m or moreseem to be devoid of fluting. Farther south, the fluted surface either is mantled by thicker loess or was formed in it. The aligned features disappear abruptly northeastward at the edge of the Wisconsinan till (Tipton and Steece, 1965) and fade out southward in Nebraska.

At least three hypotheses that seem relevant to the fluted topography have been offered for oriented drainage in the Great Plains. First, Russell (1929) suggested longitudinal dunes that controlled the smaller streams but have since been destroyed by erosion. Second, Rahn and Frazee (1974; Rahn, 1976) noted that many of the streams in southwestern South Dakota that are aligned NW -SE follow fracture patterns in the Pierre Shale, and structure may have controlled their orientation. Third, Beaty (1975) has pointed out that the alignment of coulees in south-western Alberta is parallel to the flow direction of the strongest chinook winds from the Rocky Mountains and that wind erosion is the most reasonable hypothesis for their origin. Baker (1948, 1951), Crandall (1958) and Tipton and Steece (1965) have also suggested wind action for central and eastern South Dakota lineations, as did Hallberg (1979) for western Iowa.

Because the fluted topography of northeastern Nebraska and eastcentral South Dakota is developed across glacial sediments-till, sand, and gravel- as well as on shale and chalk, structural control seems unlikely. Neither is there any evidence of longitudinal dunes that might have caused the orientation. A modification of the wind origin hypothesis is favored by the author. It is suggested that the forms in central South Dakota and northeastern Nebraska are relic yardangs, or winderoded ridges (Blackwelder, 1934; Whitney, 1985). The author follows Baker (1948, 1951), who suggested this possibility for some of the linear topographic features in west-central South Dakota and the South Dakota Badlands. Both small-scale and large-scale linear ridges and troughs aligned parallel with the prevailing wind direction can be explained as an effect of aerodynamic processes that create and accompany vortices (Whitney, 1978, 1983). Lift, created by negative airflow, as well as abrasion, is responsible for the erosion and removal of material from troughs and the shaping of the positive linear features that 
remain. Wind velocities attained in vortex movement and the subsequent venturi effect of airflow through the troughs could readily have eroded the soft sediments, with sand, silt and snow as abrasive tools.

The scarcity of pre-Wisconsinan soil profiles on the tills of northeastern Nebraska may also be relevant to this discussion. The Loveland Formation, the Sangamon Soil and the Gilman Canyon Formation (a thin, accretional Early Wisconsinan loess) are missing from most of the region, and, typically, the Peoria Loess lies directly on pre-Illinoian sediments or bedrock. Clearly, upland erosion was extensive prior to the accumulation of Peoria Loess. Deflation of dry, frost-loosened clayey silt and abrasion by wind-driven sand in the zone marginal to the advancing Wisconsinan glacier accounts for the lack of a pre-Wisconsinan weathered zone as well as the presence of a lag of wind-abraded cobbles and the development of yardangs.

Recently, Krueger (1986) has ascribed oriented lakes of the loess plains (locally known as the 'Rainbasin region') in southeast-central Nebraska. (Figure 1) to wave erosion on the margins of shallow ephemeral ponds in depressions that had formed by deflation. He placed the time of the deflation about 20000-22000 years ago, on the basis of radiocarbon dates obtained from organic matter in sediments that had been deflated by strong northwest winds and then accumulated as lunate ridges on the southeast edges of the basins. The large, massive dunes in the Nebraska Sandhills (Figure 1) were also formed by strong northwest unidirectional winds. Radiocarbon dates indicate that active dune migration was extensive during the Holocene (Ahlbrandt et al., 1983; Swinehart and Diffendal, 1989), but the region could have been an active dunefield earlier.

\section{Chronology}

The sand-wedge polygons in northeastern Nebraska are buried beneath a thin veneer of Peoria Loess, which accumulated in eastern Nebraska between 25,000 and 14,000 years ago. Enclosing dates for the several Wisconsinan tills of South Dakota are 28,700 \pm 800 years (W-1045) and about 12000 years BP. (Lemke et al., 1965; Hallberg and Kemmis, 1986). The most reasonable hypothesis for the period of wind scour and permafrost occurrence is the time of maximum extent of the Wisconsinan glaciation, 22 ooo-18 ooo years ago, as in Illinois 
(Johnson, 1986, 1990) and Indiana (Wayne, 1967). The frequency with which thermal contraction cracking takes place in permafrost regions depends on local conditions such as variations in snow cover, sedimentological characteristics and the rapidity of temperature change in the early-mid winter period. Therefore, the size of relic sand wedges or ice-wedge casts provides no estimate of the length during which permafrost conditions existed.

\section{Conclusions}

Sand-wedge casts in northeastern Nebraska 25-50 km south of the Wisconsinan glacier margin, and extensive fluted and grooved topography along the glacial margin across South Dakota, northeastern Nebraska and northwestern Iowa, indicate that a windswept tundra zone of continuous permafrost, perhaps as much as $50 \mathrm{~km}$ wide, existed during Late Wisconsinan time. Mean annual air temperatures near the ice margin must have been at least $-6^{\circ}$ to $-8^{\circ} \mathrm{C}$ and may have been as low as $\_12^{\circ}$ to $-20^{\circ} \mathrm{C}$. The zone was characterized by very strong winds, low precipitation and rapid temperature changes during winter. This represents a mean annual air temperature at least $16{ }^{\circ} \mathrm{C}$ lower than present. The strong winds deflated pre-Wisconsinan soil profiles, leaving ventifacts and lag gravels, and created troughs and ridges-interpreted as yardangs-in the region that lay just beyond the edge of the ice sheet. The wedges and yardang-like topography probably formed at the time of maximum Wisconsinan glaciation and climatic severity, when the ice margin reached the northern edge of $\mathrm{Ne}$ braska, between 22000 and 18000 years BP.

Acknowledgments - I should like to express my appreciation to Dr A. L. Washburn and to the late Dr Robert F. Black for their constructive comments and suggestions regarding the Hartington outcrop and its interpretation, and to Dr Robert Guthrie, who provided a forum on several occasions. The manuscript has been improved as a result of critical reading by Dr. John Bluemle, W. Hilton Johnson, Brainerd Mears, Jr. and James C. Walter, and an unidentified reviewer. I thank them sincerely for their constructive comments. I should also like to thank the City Clerks of Hartington, Nebraska, for allowing me access to the site on several occasions, and the US Department of Agriculture Soil Conservation Service personnel, who made a ground-reading radar traverse of part of the site. 


\section{References}

Ahlbrandt, T. S., Swinehart, J. B. and Maroney, D. G. (1983). The dynamic Holocene dunefield of the Great Plains and Rocky Mountain Basins, U.S.A. In Brookfield, M. E. and Ahlbrant, T. S. (Eds), Eolian Sediments and Processes, Developments in Sedimentology, Vol 38. Elsevier, Amsterdam, pp. 379-406.

Ahlbrandt, T. S., and Fryberger, S. E. (1980). Eolian deposits in the Nebraska Sand Hills. U.S. Geological Survey Professional Paper 1120A, pp. 1-24.

Baker, C. L. (1948). The Pennington-Haakon County Central Boundary Area with General Discussion of Its Surroundings. South Dakota State Geological Survey Report of Investigations No. 64. 28 pp.

Baker, C. L. (1951). Yardangs in South Dakota badlands. Geological Society of America, Bulletin, 62, 1532.

Baker, R. G. and Waln, K. A. (1985). Quaternary pollen records from the Great Plains and central United States. In Bryant, V. and Holloway, R. (Eds), Pollen Records of Late-Quaternary North American Sediments. American Association of Stratigraphic Palynologists Foundation, Dallas, pp. 191-203.

Beaty, C. B. (1975). Coulee alignment and the wind in southern Alberta, Canada. Geological Society of America, Bulletin, 86, 119-128.

Berg, T. E. (1969). Fossil sand wedges at Edmonton, Alberta, Canada. Biuletyn Periglacjalny, 19, 325-333.

Berg, T. E. and Black, R. F. (1966). Preliminary measurements of growth of nonsorted polygons, Victoria Land, Antarctica. In Tedrow, J. F. C. (Ed.) Antarctic Soils and Soil-forming Processes. American Geophysical Union, Antarctic Research Series, Vol. 8, pp.61-108.

Black, R. F. (1965). Ice-wedge casts of Wisconsin. Wisconsin Academy of Science, Arts and Letters, 54, 187-222.

Black, R. F. (1976). Periglacial features indicative of permafrost: ice and soil wedges. Quaternary Research, 6,3-26.

Blackwelder, E. (1934). Yardangs. Geological Society of America, Bulletin, 45, 159-166.

Bluemle, J. P. and Clayton, Lee (1986). Permafrost Features in Southwestern North Dakota. North Dakota Academy of Science, Proceedings, 40. p 15.

Brown, R. J. E. and Pewe, T. L. (1973). Distribution of permafrost in North America and its relationship to the environment: a review, 1963-1973. In Permafrost, North American Contribution to the Second International Conference, National Academy of Sciences, Washington, D.C., pp. 71-100.

Carter, L. D. (1983). Fossil sand wedges on the Alaskan arctic coastal plain and their paleoenvironmental significance. In Proceedings Fourth International Congress on Permafrost. National Academy of Sciences, Washington, D.C., pp. 109-114.

Clayton, Lee (1980). Geologic map of North Dakota, 1:5,0oo,ooo. U.S. Geological Survey and N.D. Geological Survey.

Clayton, Lee, and Bailey, P. K. (1970). Tundra polygons in the northern Great Plains. Geological Society of America Abstracts with Programs, 2, 382.

Clayton, Lee, Moran, S. R. and Bluemle, J. P. (1980). Explanatory Text to Accompany the Geologic Map of North Dakota. North Dakota Geological Survey, Report of Investigation, No. 69. 93 pp. 
Colton, R. B. (1955). Geology of the Wolf Point Quadrangle, Montana. U.S. Geological Survey Map GQ 67.

Crandall, D. R. (1958). Geology of the Pierre Area, South Dakota. U.S. Geological Survey Professional Paper 307. 83 pp.

Dillon, L. S. (1956). Wisconsin climate and life zones in North America. Science, $123,167-176$.

Flint, R. F. (1955). Pleistocene Geology of Eastern South Dakota. U.S. Geological Survey Professional Paper 262. 173 pp.

Frest, T. J. and Rhodes, R. S. I. I. (1981). Oreohelix strigosa cooperi (Binney) in the midwest Pleistocene. Nautilus, 95, 47-55.

Frye, J. C. and Willman, H. B. (1958). Permafrost features near the Wisconsinan glacial margin in Illinois. American Journal of Science, 256, 518-524.

Guthrie, R. S. (1990). The Geology and Distribution of Oriented Landforms and Associated Features in Northeastern Nebraska. PhD dissertation, University of Nebraska, Lincoln, Nebraska. 125 pp.

Hallberg, G. R. (1979). Wind-aligned drainage in loess in Iowa. Iowa Academy of Science Proceedings, 86, 4-9.

Hallberg, G. R. and Kemmis, T. J. (1986). Stratigraphy and correlation of the glacial deposits of the Des Moines and James Lobes and adjacent areas in North Dakota, South Dakota, Minnesota, and Iowa. In Sibrava, V., Bowen, D. Q. and Richmond, G. M. (Eds), Quaternary Glaciations in the Northern Hemisphere. Quaternary Science Reviews, 5, 65-68.

Hamilton, T. D., Ager, T. A. and Robinson, S. W. (1983). Late Holocene ice wedges near Fairbanks, Alaska, U.S.A: environmental setting and history of growth. Arctic and Alpine Research, 15, 157-168.

Johnson, W. H. (1986). Permafrost features in central Illinois and their environmental significance. American Quaternary Association, Program and Abstracts, pp. 37-39.

Johnson, W. H. (1990). Ice-wedge casts and relict patterned ground in central Illinois and their environmental significance. Quaternary Research, 33, 51-72.

Karte, J. (1983). Periglacial phenomena and their significance as climatic and edaphic indicators. Geojournal, 7, 329-340.

Karte, J. and Liedke, H. (1981). The theoretical and practical definition of the term 'periglacial' in its geographical and geological meaning. Biuletyn Peryglacjalny, 28, 123-135.

Kolstrup, Else (1983). Cover sands in southern Jutland (Denmark). In Proceedings Fourth International Conference on Permafrost. National Academy of Sciences, Washington, D.C., pp. 639-644.

Kolstrup, Else and Jorgensen, J. P. (1982). Older and younger cover sand in southern Jutland (Denmark). Geological Society of Denmark Bulletin, 30, 71-77.

Krueger, J. P. (1986). Development of Oriented Lakes in the eastern Rainbasin Region of Southeastern Nebraska. MS thesis, Department of Geology, University of Nebraska, Lincoln, Nebraska. 115 pp.

Lachenbruch, A. H. (1962). Mechanics of Thermal Contraction Cracks and Ice-wedge Polygons in Permafrost. Geological Society of America Special Paper 70. 69 pp.

Lemke, R. W., Laird, W. M., Tipton, M. J. and Lindvall, R. M. (1965). Quaternary geology of Northern Great Plains. In Wright, H. E., Jr. and Frey, D. G. (Eds), The Quaternary of the United States. Princeton University Press, Princeton, N.J., pp. 15-27. 
Leonard, A. B. (1952). Illinoian and Wisconsinan Molluscan Faunas in Kansas. University of Kansas Paleontological Contributions, Mollusca, Article 4. 38 pp.

Mears, Brainerd, Jr. (1981). Periglacial wedges and the late Pleistocene environment of Wyoming's intermontane basins. Quaternary Research, 15, 171-198.

Mears, Brainerd, Jr. (1986). Pleistocene periglacial wedges and temperature departures in Wyoming basins. American Quaternary Association, Program and Abstracts, pp. 55-57.

Mears, Brainerd, Jr. (1987). Late Pleistocene Periglacial Wedge Sites in Wyoming: An Illustrated Compendium. Wyoming Geological Survey Memoir No.3. 77 pp.

Neal, J. T. and Motts, W. S. (1967). Recent geomorphic changes in playas of western United States. Journal of Geology, 75, 511-525.

Pewe, T. L. (1959). Sand-wedge polygons (tesselations) in the McMurdo Sound region, Antarctica-A progress report. American Journal of Science, 257, 545-552.

Pewe, T. L. (1966). Ice-wedges in Alaska-classification, distribution, and climatic significance. In Permafrost International Conference Proceedings. National Academy of Sciences Publication 1287, pp. 76-81..

Pewe, T. L. (1983). The periglacial environment in North America during the Late Pleistocene. In Wright, H. E., Jr. (Ed.), Late Quaternary Environments of the United States, Vol. 1. University of Minnesota Press. 407 pp.

Potzger, J. E. (1951). The fossil record near the glacial border. Ohio Journal of Science, 51, 126-133.

Rahn, P. H. (1976). Coulee alignment and the wind in southern Alberta, Canada: Discussion. Geological Society of America, Bulletin, 87, 187.

Rahn, P. H., and Frazee, C. J. (1974). Drainage alignment in eastern Pennington County, South Dakota. South Dakota Academy of Science, Proceedings, 53, 61-68.

Romanovskij, N. N. (1973). Regularities in formation of frost-fissures and development of frost-fissure polygons. Biuletyn Peryglacjalny, 23, 237-277.

Ruegg, G. H. J. (1983). Periglacial eolian evenly laminated sandy deposits in the Late Pleistocene of NW Europe, a facies unrecorded in modern sedimentological handbooks. In Brookfield, M. E. and Ahlbrandt, T. S. (Eds), Eolian Sediments and Processes. Elsevier, Amsterdam, pp. 455-482.

Ruhe, R. V. (1969). Quaternary landscapes in Iowa. Iowa. State University Press, Iowa, $255 \mathrm{pp}$.

Russell, W. L. (1929). Drainage alignment in the western Great Plains. Journal of Geology, 37, 249-255.

Simpson, H. E. (1960). Geology of the Yankton Area, South Dakota and Nebraska. U.S. Geological Survey Professional Paper 328. 124 pp.

Svensson, H. (1988). Recent frost fissuring in a coastal area of southwestern Sweden. Norsk Geografisk Tidsskrift, 42, 271-277.

Swinehart, J. B., and Diffendal, R. F., Jr. (1989). Geology. In Bleed, A. and Flowerday, C. (Eds), An Atlas of the Sandhills. Nebraska Conservation and Survey Division Resource Atlas No.5, pp. 29-55.

Tipton, M. J. and Steece, F. V. (1965). Introduction to Pleistocene of Big Sioux River basin in South Dakota. In Schultz, C. B. and Smith, H. T. U. (Eds), Guidebook for Field Conference C, Upper Mississippi Valley. INQUA. Congress VIII, pp. 11-29.

Todd, J. E. (1899). The Moraines of Southeastern South Dakota and Their Attendant Deposits. U.S. Geological Survey; Bulletin, 158. 171 pp. 
Washburn, A. L. (1980). Geocryology. Wiley, New York. 406 pp.

Washburn, A. L., Smith, D. D. and Goddard, R. H. (1963). Frost cracking in a middle-latitude climate, Biuletyn Peryglacjalny, 12,175-189.

Wayne, W. J. (1963). Pleistocene Patterned Ground and Periglacial Temperatures in Indiana. Geological Society of America Special Paper 76, pp. 176-177.

Wayne, W. J. (1967). Periglacial features and climatic gradient in Illinois, Indiana, and western Ohio, east-central United States. In Cushing, E. J. and Wright, H. E. Jr. (Eds), Quaternary Paleoecology. Yale University Press, New Haven, pp. 393-414.

Wayne, W. J. (1985). Drainage patterns and glaciations in eastern Nebraska. TERQUA Symposium Series, 1, 111-117.

Wayne, W. J. (1988). Timing of the Late Wisconsinan diversion of the Missouri River into the Elkhorn Platte basin. Nebraska Academy of Sciences, Proceedings, April, $50 A$.

Westgate, J. A. and Bayrock, L. A. (1964). Periglacial structures in the Saskatchewan gravels and sands of central Alberta, Canada. Journal of Geology, 72, 641-648.

White, E. M. (1961). Drainage alignment in western South Dakota. American Journal of Science, 259, 207-210.

White, E. M. (1970). Giant desiccation cracks in central South Dakota soils. Soil Science, 110, 71-73.

Whitney, M. I. (1978). The role of vorticity in developing lineation by wind erosion. Geological Society of America, Bulletin, 89, 1-18.

Whitney, M. I. (1983). Eolian features shaped by aerodynamic and vorticity processes. In Brookfield, M. E., and Ahlbrandt, T. S. (eds), Eolian Sediments and Processes. Elsevier, Amsterdam, pp. 223-245.

Whitney, M. I. (1985). Yardangs. Journal of Geological Education, 33, 93-100. 